\title{
WYBRANE PORTRETY KOBIET BEATYFIKOWANYCH ZA PONTYFIKATU PAPIEŻA FRANCISZKA
}

\section{Wstęp}

Po sede vacante trwającym od wieczora 28 lutego 2013 r. ${ }^{1}$ kardynałowie zebrani na konklawe 13 marca 2013 r. wybrali na 266. Następcę Świętego Piotra Argentyńczyka kard. Jorge Mario Bergoglio (ur. 17 grudnia 1936 r.), jezuitę ${ }^{2}$. Nowy Biskup Rzymu program pontyfikatu zawarł w imieniu Franciszek ${ }^{3}$ i motcie Miserando Atque Eligendo („,Spojrzał z miłosierdziem i wybrał") $)^{4}$.

Kwerenda źródłowa przeprowadzona w Bibliotece Papieskiego Uniwersytetu Gregoriańskiego w Rzymie oraz w Bibliotece Papieskiego Wydziału Teologicznego „Seraphicum” w Rzymie (25-29 listopada 2019 r.) została sfinansowana z grantu dyscyplinowego pt. Prawo i praktyka kanonizacyjna za pontyfikatu papieża Franciszka.

* Dr hab.; adiunkt w Katedrze Historii, Norm Ogólnych, Prawa Sakramentów i Instytutów Życia Konsekrowanego na Wydziale Prawa, Prawa Kanonicznego i Administracji KUL, e-mail: lfiejda@kul.pl; https:/ / orcid.org/0000-0001-6252-4027.

1 Sedes vacans ob renuntiationem a Pontificatu Benedicti PP. XVI (28.02.2013), Acta Apostolicae Sedis (dalej: AAS) 105(2013), s. 336.

2 Jorge Mario Bergoglio, L'Osservatore Romano, wyd. pol. (dalej: OR) 34(2013), nr 5(352), s. 5. Szerzej zob. np.: Vi chiedo di pregare per me: inizio del ministero petrino di papa Francesco, Città del Vaticano 2013; G. Valente, Francesco, un papa dalla fine del mondo: la persona, le idee, lo stile, Bologna 2013; A. Ivereigh, Tempo di misericordia: vita di Jorge Mario Bergoglio, Milano 2014; A. Mariani, Papa Francesco: misericordia, povertà e servizio: per una vita buona in compagnia di Maria, presentazione di Egidio Chiarella, Roma 2014; M. Borghesi, Jorge Mario Bergoglio: biografia intelektualna: dialektyka i mistyka, tłum. D. Chodyniecki, Kraków 2018.

3 Papież, który przyjąt imię Franciszek, OR 34(2013), nr 5(352), s. 3; Franciszek - imię, które jest programem pontyfikatu, Niedziela 2013, nr 26, s. 4-5.

4 Herb i motto Papieża Franciszka, OR 34(2013), nr 5(352), s. 17. 
Kilka dni po wyborze na papieża w przemówieniu skierowanym do korpusu dyplomatycznego akredytowanego przy Stolicy Apostolskiej papież Franciszek, czerpiąc z wzoru Biedaczyny z Asyżu, nakreślił program swojego pontyfikatu: 1) troszczyć się i otaczać opieką tych, którzy cierpią z powodu materialnej i duchowej nędzy; 2) działać na rzecz budowania prawdziwego pokoju, bowiem - jak ocenia papież -

Nie może być prawdziwego pokoju, jeśli każdy jest miarą samego siebie, jeśli każdy może domagać się zawsze i wyłącznie swojego prawa, nie troszcząc się równocześnie o dobro innych, wszystkich, począwszy od natury, która łączy wszystkie istoty ludzkie na tej ziemi;

3) jako Pontifex (tj. „ten, który buduje mosty”) poprzez dialog budować mosty z Bogiem i między ludźmi, „tak aby każdy mógł znaleźć w drugim nie wroga, nie konkurenta, lecz brata, którego można przyjąć i uściskać" 5 .

Program pontyfikatu Głowa Kościoła realizuje przez liczne beatyfikacje i kanonizacje, przez które ukazuje, że święci są przykładami i przewodnikami życia chrześcijańskiego. „Nie są jakimiś nieosiągalnymi istotami, ale pozostają nam bliscy i mogą podtrzymywać nas na drodze życia”. Ich świadectwo "oświeca nas, pociąga oraz stawia przed nami wyzwania, ponieważ jest «Słowem Bożym» wcielonym w historię i przez to pozostaje nam bliskie" ${ }^{\prime 6}$. Na ten dydaktyczny wymiar beatyfikacji i kanonizacji zwrócił uwagę 12 grudnia 2019 r. w przemówieniu do członków Kongregacji Spraw Kanonizacyjnych, jej urzędników i współpracowników z okazji 50. rocznicy utworzenia tej dykasterii Kurii Rzymskiej”, która ze skrupulatnością, dokładnością, obiektywizmem i rygorem na każdym etapie dochodzenia studiuje dokumenty procesowe dotyczące męczeństwa,

5 Franciszek, Działajcie na rzecz budowania pokoju, 22 III - Audiencja dla korpusu dyplomatycznego akredytowanego przy Stolicy Apostolskiej, OR 34(2013), nr 5(352), s. 26.

6 Francesco: la santità è la parola di Dio incarnata nella storia, https:/ / www.vaticannews.va/ it/papa/news/2019-12/papa-francesco-udienza-congregazione-delle-cause-dei-santi.html [dostęp: 6.01.2020 r.].

7 Zob. Paulus PP. VI, Motu proprio datae Processus de Causis beatificationis et canonizationis aptius ordinantur Sanctitas clarior (19.03.1969), AAS 61(1969), s. 49-153; tenże, Constitutio apostolica Sacra Rituum Congregatio in duas Congregationes dividitur, alteram pro Cultu Divino, alteram pro Causis Sanctorum (8.05.1969), AAS 61(1969), s. 297-305. 
heroiczności cnót, cudu ${ }^{8}$, a także - od 11 lipca 2017 r. - ofiarowania życia9 Jednym z prawnych wymogów weryfikowanych w każdej fazie procesu beatyfikacyjnego jest przesłanie, czyli walor eklezjalny sprawy (momentum ecclesiale ${ }^{10}$, tak mocno wyeksponowany w niniejszej pracy.

Ze względu na szczególny charakter artykułu dedykowanego dr Kindze Stasiak, dobór postaci nie jest przypadkowy. Są to kobiety, które postawą, talentami, praktyką cnót w codzienności, różnorodnością pasji i zadań, nie tylko przypominają dr K. Stasiak, lecz także z pewnością ich biografie byłyby dla niej fascynującą lekturą. Zasadniczą część artykułu poprzedzają rozważania papieża Franciszka o świętości, będącej „najpiękniejszym obliczem Kościoła"11.

\section{1. Świętość w ujęciu papieża Franciszka}

W centrum nauczania o świętości papież Franciszek stawia Jezusa Chrystusa będącego „obliczem miłosierdzia Ojca”12. Tym, który „każe nam iść naprzód drogą świętości”13 jest Duch Święty, przez Jego namaszczenie „nasze człowieczeństwo zostaje naznaczone świętością Jezusa

8 Francesco: la santità è la parola di Dio...

9 Francesco, Lettera apostolica in forma di Motu Proprio del Sommo Pontefice Francesco Maiorem hac dilectionem sull'offerta della vita, Bollettino z 11.07.2017 r., nr B0484. Komentarz do dokumentu zob.: M. Inglot, Ofiarowanie życia jako droga do świętości kanonizowanej wedtug motu proprio papieża Franciszka Maiorem hac dilectionem z 11 lipca 2017 r., w: Prawo i praktyka kanonizacyjna za pontyfikatu papieża Franciszka, red. L. Fiejdasz-Buczek, Lublin 2019, s. 57-71.

10 Podstawy prawne waloru eklezjalnego sprawy, jego znaczenie w procesie kanonizacyjnym analizuje L. Fiejdasz-Buczek w monografii Sprawy kanonizacyjne za pontyfikatu papieża Benedykta XVI. Studium prawno-kanoniczne, Lublin 2019, s. 326-328.

11 Adhortacja apostolska Ojca Świętego Franciszka Gaudete et exsultate o powołaniu do świętości w świecie współczesnym, Wrocław 2018. Tekst źródłowy zob. Franciscus, Adhortatio Apostolica Gaudete et Exsultate de vocatione ad sanctitatem in mundo huius temporis (19.03.2018), AAS 110(2018), s. 1111-1161.

12 Franciscus, Litterae apostolicae Misericordia et misera de Iubilaeo Extraordinario Misericordiae concludendo, Datum Romae, apud S. Petrum, die XX mensis Novembris, in sollemnitate Domini Nostri Iesu Christi, Universorum Regis, Anno Domini MMXVI, (11.04.2015), AAS 108(2016), s. 1311-1327.

13 Ducha nie można poskramiać, 16 kwietnia, OR 34(2013), nr 6(353), s. 21. 
Chrystusa i uzdalnia nas do miłowania braci tą samą miłością, którą miłuje nas Bóg"14. Maryja jest wzorem ewangelicznej doskonałości ${ }^{15}$.

Ona - pisze papież - jest Świętą pośród świętych, najbardziej błogosławioną, Tą, która nam ukazuje drogę świętości i nam towarzyszy"16. „Maryja Panna uczy, jak patrzeć i przygarniać: chorych, opuszczonych, ubogich, dalekich, młodzież przeżywającą trudności ${ }^{17}$.

Papież Bergoglio zauważa, że świętości nie można osiągnąć wyłącznie o własnych siłach. Jest ona owocem łaski, darem Boga oraz „wolnym i odpowiedzialnym" włączeniem się w Jego plan $^{18}$. Odkrywając swoje powołanie i odpowiadając na nie, człowiek może stać się „świętym w miłości”. A przyjmując w sobie „świętość jako dar łaski, nie może nie przekładać jej na konkretne działanie w życiu codziennym"19. Mówiąc inaczej,

Liczy się to, aby każdy wierny rozpoznał swoją drogę i wydobył z siebie to, co ma najlepszego, to, co najbardziej osobistego Bóg w nim umieścił (por. 1 Kor 12,7), a nie marnował sił, usiłując naśladować coś, co nie było dla niego pomyślane ${ }^{20}$.

Papież Franciszek zachęca do spoglądania na przykłady życia świętych, gdyż „przyczyniają się do rozwoju Kościoła, prowadząc go drogą pokory, miłości, serca, piękna"21. Podczas modlitwy maryjnej 1 listopada 2019 r. papież przypomniał, że święci i święte każdej epoki nie są tylko symbolami, postaciami historycznymi, niedosięgłymi. Są to ludzie,

„którzy żyli stąpając po ziemi, doświadczali codziennego trudu egzystencji, z jej sukcesami i porażkami, i w Panu znajdowali siłę, żeby wciąż się podnosić

14 Franciszek, Duch przygotowuje, namaszcza i posyła, $24 \mathrm{~V}$ - Homilia podczas Mszy św. na Stadionie Międzynarodowym w Ammanie, OR 35(2014), nr 6(362), s. 6.

15 Ewangeliczna doskonałość, 13 X - «Anioł Pański» po Mszy św. kanonizacyjnej, OR 40(2019), nr 11(417), s. 20.

16 Gaudete et exsultate..., nr 176.

17 Wizyta papieża w Cagliari na Sardynii 22 września 2013 r., OR 34(2013), nr 11(356), s. 20.

18 Dialog w rodzinie, 29 grudnia, [Modlitwa maryjna z Papieżem], OR 41(2020), nr 1(419), s. 37.

19 Przestanie proste i wielkie, 5 stycznia, [Modlitwa maryjna z Papieżem], OR 41(2020), nr 1(419), s. 39.

20 Gaudete et exsultate..., nr 11.

21 Kościót wolny od ideologii, 19 kwietnia, OR 34(2013), nr 6(353), s. 23. 
i iść dalej”22. "Święci, - jak pisał papież w Przestaniu z okazji 500. rocznicy urodzin św. Teresy z Avili - bardziej niż odważnymi bohaterami, są owocem łaski Bożej okazanej ludziom. Każdy święty ukazuje nam jeden rys wielokształtnego oblicza Boga"23.

\section{Z kolei w bulli Misericordiae vultus pisze, że}

Kościół żyje komunią Świętych. W Eucharystii komunia ta, która jest darem Boga, aktualizuje się jako jedność duchowa, która łączy nas wierzących ze Świętymi i Błogosławionymi, których liczba jest niepoliczona (por. Ap 7,4). Ich świętość przychodzi z pomocą naszej słabości i w ten sposób Matka-Kościół jest zdolna, wraz ze swoją modlitwą i ze swoim życiem, wyjść naprzeciw słabości jednych w świętości innych ${ }^{24}$.

\section{Wezwanie do „śswiętości codziennej"25}

Papież bardzo mocno akcentuje uświęcanie się w zwyczajnych okolicznościach życia codziennego. Wyjaśnia, że powołanie do świętości nie jest czymś nadzwyczajnym! Miarą świętości nie są „widzenia lub modlitwy na bardzo wysokim poziomie”, przybieranie wyglądu „jak ze świętego obrazka”. Świętość jest „powołaniem normalnym”. Żyć po chrześcijańsku to "znaczy tyle, co «żyć jak święty»"; to postępować "zgodnie z tym, co Pan nam mówi o świętości”, pokładając "całą nadzieję w łasce, która wam przypadnie przy objawieniu Jezusa Chrystusa" 26 ; to

podejmować codzienne zobowiązanie do uświęcania się w warunkach, w zo-

bowiązaniach i okolicznościach naszego życia, starając się przeżywać wszystko z miłością, z miłosierdziem ${ }^{27}$.

22 Świętość jest wezwaniem, 1 listopada, [Modlitwa maryjna z Papieżem], OR 40(2019), nr 12(418), s. 30.

23 Franciszek, Święta wędrownica. Przestanie z okazji 500. rocznicy urodzin św. Teresy z Avili, OR 35(2014), nr 11(366), s. 34.

${ }^{24}$ Misericordiae vultus, nr 22; tłum. za: Papież Franciszek, Bulla ogłaszająca Nadzwyczajny Jubileusz Miłosierdzia Misericordiae vultus, (11.04.2015 r.), OR 36(2015), nr 5(371), s. 14.

25 Franciszek, Świętość jest wolnościa, 29 maja, OR 39(2018), nr 7(404), s. 59.

26 Tamże, s. 58.

27 Świętość jest wezwaniem..., s. 30. 
Tak jak czynili to męczennicy, którzy „pomimo prześladowań są ludźmi pokoju". Przekazują nam dziedzictwo, które trzeba zachowywać i naśladować - Ewangelię miłości, miłosierdzia i przebaczenia. Ich świadectwo jest najskuteczniejsze ${ }^{28}$. Ale najlepszym narzędziem do ewangelizowania młodych ludzi jest „inny młody człowiek" 29 , Ewangelia bowiem głoszona z pasją i radością „poprzez chrześcijańskie świadectwo, ma moc zburzyć nawet najwyższe mury" ${ }^{30}$. I to właśnie radość jest ważną cechą świętości ${ }^{31}$. Inną jest wolność, która pozwala zerwać „ze schematami światowymi” wiążącymi w pozornym dobrobycie, sposobie myślenia i osądzania ${ }^{32}$. Zdaniem papieża specyfikę powołania do świętości duszą m.in. takie postawy jak: klerykalizm, niepotrzebna rywalizacja, karierowiczostwo, sztywność i negatywne nastawienie ${ }^{33}$.

Najpełniej nauczanie o powołaniu do świętości w świecie współczesnym wyjaśnił papież Franciszek w adhortacji apostolskiej Gaudete et exsultate. Jednakże w kontekście założeń niniejszego artykułu warto zwrócić uwagę na dwa elementy tego ważnego dokumentu. Pierwszy - Ojciec Święty pisze o świętych coram Deo, tych niekanonizowanych, a nawet tych, żyjących współcześnie. W ich wytrwałości,

aby iść naprzód, dzień po dniu, widzę świętość Kościoła walczącego. Jest to często „świętość z sąsiedztwa”, świętość osób, które żyją blisko nas i są

28 Ewangelia miłości i miłosierdzia, 17 listopada 2019 r., III Światowy Dzień Ubogich w Watykanie, OR 40(2019), nr 12(418), s. 18.

29 Franciszek, 28 VII - Msza św. na zakończenie XXVIII Światowego Dnia Młodzieży Bez obawy, idźcie stużyć, OR 34(2013), nr 8-9(364), s. 17.

30 Francesco, È l'ora di rimboccarsi le maniche. In un messaggio al laicato spagnolo il Papa denuncia le tante voci di morte e di disperazione che soffocano la vecchia Europa, 14 febbraio 2020, Festa dei santi Cirillo e Metodio, Patroni dell'Europa, L'Osservatore Romano Giornale Quotidiano, sabato 15 febbraio 2020, Anno CLX n. 37(48.361), s. 9.

31 „Prawdziwa świętość jest radością, ponieważ «smutny święty jest smutnym obrazem świętego»". Franciszek, Święta wędrownica..., s. 34. Zob. także Franciszek, Wiarygodni i konsekwentni, 6 VII - Spotkanie z seminarzystami, nowicjuszami i nowicjuszkami, OR 34(2013), nr 8-9(354), s. 42.

32 Franciszek, Świętość jest wolnościa..., s. 58; tenże: Wolni od ambicji i karierowiczostwa, 6 VI - Audiencja dla wspólnoty Papieskiej Akademii Kościelnej, OR 34(2013), nr 8-9(335), s. 30; tenże, Kościót musi się ogołocić ze światowości, Przemówienie do ubogich, bezrobotnych i imigrantów, którymi opiekuje się Caritas, w Sali Obnażenia w siedzibie biskupiej [Asyż, 4.10.2013 r.], OR 34(2013), nr 11(356), s. 9-11.

33 Francesco, È l'ora di rimboccarsi le maniche..., s. 9. 
odblaskiem obecności Boga albo, by użyć innego wyrażenia, są „klasą średnią świętości" ${ }^{\prime \prime}$.

Drugi element - papież Franciszek świętych coram eccelsiae przestawia jako jasne wzory do naśladowania ${ }^{35}$. Wśród nich szczególne miejsce zajmują kobiety, a dokładniej „kobiecy geniusz”. Przejawia się on w "kobiecych stylach świętości, niezbędnych do odzwierciedlenia świętości Boga". Szczególne zasługi kobiety oddały w czasach, gdy były najbardziej wykluczane. Działalność świętej Hildegardy z Bingen, Brygidy Szwedzkiej, Katarzyny Sieneńskiej, Teresy z Ávili i Teresy z Lisieux spowodowała „nowe dynamiki duchowe i ważne reformy w Kościele”36.

\section{Wzory kobiet w praktyce beatyfikacyjnej papieża Franciszka}

Wśród beatyfikowanych kobiet jest pierwsza świecka Meksykanka Concepción Cabrera de Armida (1862-1937), żona, matka, pisarka, mistyczka, założycielka trzech stowarzyszeń katolickich i dwóch zgromadzeń zakonnych. Kardynał Giovanni Angelo Becciu w homilii beatyfikacyjnej 4 maja 2019 r. zauważył, że „piękno i siła jej świadectwa polega na tym, że już w młodości oddała się Miłości absolutnej: Bogu”. Rozumiała, że szczęście nie polega na pogoni za własnymi pomysłami, lecz na podporządkowaniu się woli Bożej. Zainteresowanie muzyką, poezją, grą na fortepianie i śpiewem nie odciągało jej od wzorowego spełniała obowiązków wobec rodziny (była matką dziewięciorga dzieci) i pełnienia czynów miłosierdzia wobec biednych, chorych, umierających. Po siedemnastu latach małżeństwa zmarł jej mąż: „Czułam boski skalpel w mojej duszy" - pisała. Szukała wtedy ratunku i wsparcia przed tabernakulum. Jej niewyobrażalny ból pogłębił się po śmierci czwórki dzieci! Jednak i wtedy nie straciła siły spokoju i zaufania do Pana. Wpatrywała się w Ukrzyżowanego, ofiarując cierpienie w intencji zbawienia dusz, nawrócenia grzeszników, potrzeb świata i Kościoła. Naznaczona miłością do woli Bożej, była otwarta z pogodnym duchem na to, co Pan wyznaczał jej w radości i w bólu. Nowa błogosławiona niesie przesłanie zwłaszcza

\footnotetext{
34 Gaudete et exsulate..., nr 7.

35 Tamże, nr 5.

36 Tamże, nr 12.
} 
kobietom. Jako model życia apostolskiego wie, jak stworzyć wspaniałą syntezę kontemplacji i działania. Łączy w sobie postawę Marty i Marii. Jest kobietą o silnej osobowości, obdarzoną wyjątkowymi darami, zarówno ludzkimi, jak i chrześcijańskimi; jest kobietą modlitwy, gorliwości apostolskiej, uwielbia i wywyższa wielkość Boga, zajmując się jednocześnie nieszczęściami i potrzebami wielu ${ }^{37}$.

Ludziom świata nauki papież Franciszek przedstawił sylwetkę hiszpańskiej chemiczki i członkini Opus Dei Marí Guadalupe Ortiz de Landázuri Fernández de Heredia (1916-1975) - wyniesionej na ołtarze 18 maja 2019 r. w Madrycie. W liście do Prałata Opus Dei odczytanym podczas beatyfikacji papież Franciszek wyraził wdzięczność „za to świadectwo świętości, przeżywanego w zwykłych okolicznościach jej życia chrześcijańskiego" ${ }^{38}$. Znajomi z okresu studiów na wydziale chemii Uniwersytetu Central w Madrycie wspominają M. Guadalupe Ortiz jako dziewczynę spontaniczną, niezwykle sympatyczną, przykładającą się do nauki. Punktem zwrotnym w jej życiu była rozmowa z Josemaríą Escrivą de Balaguerem (25 stycznia 1944 r.). Przyszły święty wyjaśnił M. Guadalupe przesłanie Opus Dei: kochać Chrystusa „ponad wszystko poprzez pracę zawodową i codzienne zajęcia". Po odbyciu rekolekcji poprosiła o przyjęcie do Prałatury. W niej wykonywała zwykłe prace domowe i troszczyła się o akademiki w Madrycie i w Bilbao ${ }^{39}$, zmagając się z ludzkimi słabościami. W jednym z 350 listów adresowanych do ks. J. Escrivy pisała w tym czasie:

Ojcze [...] Wiesz jak ciężko jest mi zachować porządek, nie tylko w sprawach osobistych, ale także w zadaniach, które są mi powierzone. [...] staram się [...] zwracać szczególną uwagę, żeby niczego nie popsuć. Mimo tych starań wyrządziłam pewne szkody, zabrudziłam sekretarzyk i urwałam kulę od łóżka; poza tym, zdarza mi się zapomnieć, gdzie położyłam klucze i przez to niekiedy marnuję czas innych sióstr ${ }^{40}$.

37 Szerzej zob. Messa per la beatificazione di María Concepción Cabrera (Città del Messico, Messico, 4 maggio 2019). Omelia del Card. Giovanni Angelo Becciu, http:/ / www.causesanti.va/it/ santi-e-beati/maria-concepcion-cabrera-arias.html [dostęp: 7.03.2020 r.]. Tłum. N. Addiscott.

38 List Papieża Franciszka z okazji beatyfikacji Guadalupe, Watykan, 12 kwietnia 2019 r., https://opusdei.org/pl-pl/article/list-papieza-franciszka-z-okazji-beatyfikacji-guadalupe/ [dostęp: 1.04.2020 r.].

39 Wszystko z miłości do Pana Boga. Biografia, https://opusdei.org/pl-pl/article/ wszystko-z-milosci-do-pana-boga/ [dostęp: 1.05.2020 r.].

40 Bilbao, 29 października 1945 roku, w: M. Del Rincón, M.T. Escobar, Listy do Świętego, https:/ /opusdei.org/pl-pl/document/listy-do-swietego/ [dostęp: 1.05.2020 r.]. 
W 1950 r. na prośbę założyciela Opus Dei wyruszyła do Meksyku. Tam prowadziła pracę apostolską wśród kobiet z Prałatury, w stolicy otworzyła akademik dla studentek, który szybko stał się „miejscem nauki, rozwoju osobistego i formacji chrześcijańskiej". Kupiła i odnowiła zrujnowaną posiadłość Montefalco, mieszczącą w późniejszych latach szkoły oraz ośrodek rekolekcyjno-formacyjny. Od 1957 r. M. Guadalupe pracowała w zarządzie centralnym Opus Dei. Po dwóch latach ze względów zdrowotnych wróciła do Madrytu. Nie zaprzestała działalności formacyjnej oraz pracy w ośrodkach Opus Dei ${ }^{41}$. W 1965 r. z wyróżnieniem obroniła doktorat $\mathrm{z}$ chemii dotyczący izolacji materiałów ogniotrwałych $\mathrm{w}$ popiele z łusek ryżu. Uczyła fizyki w prestiżowym liceum Ramiro de Maeztu w Madrycie i jako adiunkt, a od 1967 r. profesor w Escuela Femenina de Maestría Industrial wykładała fizykę, chemię i matematykę. Rok później współtworzyła Centrum Studiów i Badań nad Gospodarstwem Domowym. Pełniła w nim funkcję zastępcy dyrektora i profesora chemii wyrobów włókienniczych ${ }^{42}$. Badała tekstylia, ich zastosowanie w pracach domowych, robiła eksperymenty (m.in. jakie substancje mają wpływ na odplamianie tkanin) ${ }^{43}$. Wszędzie nawiązywała przyjaźnie z młodymi ludźmi, którzy byli zbudowani jej wiarą, pobożnością, miłością i zdrową, zaraźliwą radością. W każdych okolicznościach była darem dla innych; szczególnie poświęcając się formacji i kształceniu studentek oraz prowadzeniu badań naukowych w celu promowania postępu ludzkości ${ }^{44}$. Pracowała niemalże do śmierci, która nadeszła 16 kwietnia 1975 r.

Arcybiskup Madrytu kard. Antonio María Rouco Varela rozpoczynając w 2001 r. proces beatyfikacyjny M. Guadalupe według norm prawa kanonizacyjnego zreformowanego przez Jana Pawła II ${ }^{45}$, w następujący

${ }^{41}$ Wszystko z mitości..., zob. przypis 43 i 46.

${ }^{42}$ M. Del Rincón, M.T. Escobar, Listy do Świętego...

43 Wszystko z miłości...

44 Beatificazione di Guadalupe Ortiz de Landázuri (Palacio de Vistalegre di Madrid, 18 maggio 2019). Omelia dell'Em.mo Card. Giovanni Angelo Becciu; zob.: http:/ / www.causesanti.va/ it/santi-e-beati/maria-guadalupe-ortiz.html [dostęp: 1.04.2020 r.].

45 Codex Iuris Canonici auctoritate Ioannis Pauli PP. II promulgatus (25.01.1983), AAS 75(1983), pars II, s. 1-317. Kodeks Prawa Kanonicznego, przekład zatwierdzony przez Konferencje Episkopatu, Poznań 1984; Ioannes Paulus PP. II, Constitutio apostolica Divinus perfectionis Magister. Modus procedenti in Causarum canonizationis instructione recognoscitur et Sacrae Congregationis pro Causis Sanctorum nova datur ordinatio (25.01.1983), AAS 75(1983), s. 349-355; Sacra Congregatio pro Causis Sanctorum, Normae servandae in inquisitionibus ab Episcopis faciendis in causis sanctorum (7.02.1983), AAS 75(1983), s. 396-403. 
sposób uzasadnił walor eklezjalny sprawy, czyli znaczenie jej ewentualnej beatyfikacji dla Kościoła:

Życie tej służebnicy Bożej przynosi Kościołowi i społeczeństwu XXI wieku kobiecość, kompetencję zawodową i pragnienie świętości; tym wszystkim Guadalupe żyła pośród świata, niestrudzenie starając się o wszechstronny rozwój kobiety.

"Kościół i świat potrzebują świeckich świętych"46. Błogłosławiona M. Guadalupe jest modelem chrześcijańskiej kobiety, „zawsze oddanej temu, do czego przeznaczył ją Bóg, zwłaszcza w sferze społecznej i naukowej" ${ }^{47}$.

W dobie pandemii COVID-19 niezwykle aktualny jest przykład życia Włoszki Aureli Mercede Stefani (1891-1930) ${ }^{48}$. Odpowiadając na misyjne powołanie, w wieku 20 lat wstąpiła do Instytutu Sióstr Misjonarek Matki Bożej Pocieszycielki, przybierając imię Irene. W ostatnich dniach 1914 r. wyruszyła ma misje do Kenii przez Mombasę i Limuru, gdzie znajdowała się jedna z pierwszych misji zgromadzenia oraz prokura misyjna, „sala gimnastyczna” (poligon) dla „afrykańskich nowicjuszy”. W Limuru s. Irene przez blisko dwa miesiące uczyła się języka kikuyu, poznawała zwyczaje tego plenienia oraz metody jego pracy: bogactwo wiedzy, którą tu zdobyła posłużyły jej w przyszłej pracy misyjnej w kolejnych wioskach i w czasie pracy w przychodniach. Następnie pieszo udała się do Nyeri, gdzie nauczała $\mathrm{w}$ sierocińcu oraz pracowała $\mathrm{w}$ gospodarstwie rolnym Mathari. Trwająca I wojna światowa przyniosła zniszczenia i cierpienie. Toteż w sierpniu 1916 r. s. Irene została przydzielona do szpitala w Voi, do służby w Czerwonym Krzyżu, gdzie w nieludzkich warunkach sanitarnych, zmagając się z brakiem leków i żywności, posługiwała umieszczonym $\mathrm{w}$ prowizorycznych szpitalach polowych tzw. przewoźnikom (Carriers Corps) zarażonym malarią i innymi śmiertelnymi chorobami ${ }^{49}$.

46 Wszystko z mitości...

47 Beatificazione di Guadalupe Ortiz de Landázuri...

48 Szerzej zob.: Parte seconda. Profilo biografico della Serva di Dio, w: CCS, P.N. 1483, Nyerien. seu Taurinen., Beatificationis et canonizationis Servae Dei Irenae Stefani (in saeculo: Mariae a Mercede), Religiosae Instituti Sororum Missionariarum a Consolata (1891-1930), Positio super vita, virtutibus et fama sanctitatis (dalej: Positio super vita), Roma 1996, s. 85-97.

49 Za poświęcenie się rannym w marcu 1919 r. została odznaczona srebrnym medalem Royal British Red Cross. Cyt. za: Parte seconda - Profilo biografico, w: Positio super vita..., s. 82. Szczegółowa biografia zob.: Informatio, w: Positio super vita..., s. 128-357; początki 
Następnie służyła chorym w Kilwa Kiwinje, Lindi i w Dar-es-Salaam (Tanzania). W opuszczonych chatach gromadzono tysiące ludzi mających na ciele cuchnące rany. Siostra Irene wykazała się niezłomną odwagą, wielką miłością i poświęceniem, niosąc ulgę cierpiącym, zawsze z życzliwością i pięknym uśmiechem. Z nadzwyczajną siłą ducha i cierpliwością opiekowała się najpoważniej chorymi, rannymi i trudnymi do leczenia pacjentami. Przybiegała na każde wezwanie, również nocą, ofiarując pomoc medyczną i duchową (nawet przyjęcie chrztu). Swoją postawą poruszała serca nie tylko chorych, lecz także lekarzy i pielęgniarek ${ }^{50}$.

Wśród wielu heroicznych czynów s. Irene uderza ten dotyczący mężczyzny o imieniu Athiambo, którego przygotowywała do chrztu. Został on ranny i nocą razem z innymi zmarłymi został przetransportowany na plażę, skąd morski prąd zabierał ciała. Szukając go nad morzem, w pierwszej chwili nie dostrzegła jego ciała. W pewnym momencie odczuła, że Athiambo może znajdować się w stosie cuchnących, napuchniętych, rannych i nagich zwłok. Rozpoczęła więc zdejmowanie "trupa po trupie", aż na samym dole rozpoznała twarz Athiambo i usłyszała jego westchnienie. Przyjąwszy chrzest, mężczyzna zmarł w pokoju. Po tym fakcie kapitan lekarz wojskowy zmienił procedury i zabronił wywożenia zwłok bez jego osobistego stwierdzenia zgonu albo potwierdzenia śmierci przez jednego z misjonarzy ${ }^{51}$.

Siostra Irene opiekowała się również zmarłymi, zwłaszcza chrześcijanami, którym ze względu na to, że są „świątynią Ducha Świętego”, chciała okazać szacunek. Ich ciała przygotowywała do pochówku, zawijała w prześcieradła, by nie zostały zabrane nagie na plażę i rzucone na stos razem $z$ innymi ciałami ${ }^{52}$.

działalności misyjnej s. Irene opisuje Redakcja czasopisma Andare alle Genti: Gli esordi di una missione straordinaria, Andare alle Genti: la rivista delle Missionarie della Consolata di informazione missionaria 69(2015), nr 9-10, s. 6-7.

50 Parte seconda. Profilo biografico..., s. 2.

51 Szerzej zob. tamże, s. 152. Zdarzenie to przytoczył kard. P. Pengo w homilii beatyfikacyjnej: Omelia di sua Eminenza, cardinal Njue, in occasione della celebrazione della beatificazione di Sr. Irene Stefani, Nyeri - Dedan Kimathi University, 23 Maggio 2015, http:/ /irene. missionariedellaconsolata.org2016/07/19/440-4-2/ [dostęp: 3.01.2020 r.].

52 Parte seconda. Profilo biografico..., s. 152. 
Swoją ziemską wędrówkę zakończyła w wieku 39 lat, 31 października 1930 r. w Gikondi w Kenii ${ }^{53}$. W akcie zgonu jako przyczynę śmierci podano zapalenie płuc (polmonite) ${ }^{54}$. Faktycznie Służebnica Boża kilka dni przed śmiercią udała się do chaty umierającego na dżumę (peste) nauczyciela Juliusa Ngari w Gathukimundu. Pomimo tego, że ów mężczyzna obraził ją (aby zająć jej miejsce, krytykował jej nauczanie), s. Irene odwiedziła go. Objęła konającego, przytuliła i "oddychała jego oddechem”, który najprawdopodobniej ją zakaził. Od tego momentu zaczęła czuć się gorzej. Lekarze zidentyfikowali ten kontakt jako polmonite pestosa wywołaną pałeczką dżumy (Yersinia pestis) ${ }^{55}$. Afrykańczycy natychmiast skomentowali jej śmierć: „zabiła ją miłość”! Silne pragnienie świętości wyraziła w ostatnich słowach: „Jestem cała Jezusa, Maryi i Józefa, teraz i zawsze przez całą wieczność" 56 .

Jej posługa misyjna sprawowana na wzór Dobrego Samarytanina, powszechna i stała opinia świętości żywa wśród ludów Kenii, Tanzanii, w zgromadzeniu misyjnym, do którego należała, i w rodzinnych Włoszech była podstawą wszczęcia procesu beatyfikacyjnego ${ }^{57}$. Ze względu na miejsce śmierci kandydatki na ołtarze proces beatyfikacyjny na temat heroiczności cnót odbył się Nyeri w Kenii (30 marca 1984 r. - 13 lutego 1987 r.). Liczne dowody znajdujące się w miejscu narodzenia i życia Służebnicy Bożej uzasadniały przeprowadzenie procesu rogatoryjnego ${ }^{58} \mathrm{~W}$ Turynie (19 października 1984 r. - 1 października 1988 r.). Dnia 29 stycznia 1993 r. Kongregacja Spraw Kanonizacyjnych wydała dekret ważności dochodzenia diecezjalnego ${ }^{59}$. Kardynałowie i Biskupi członkowie Kongregacji zgromadzeni na zebraniu zwyczajnym 15 lutego 2011 r. wyrazili pozytywną opinię $\mathrm{w}$ odniesieniu do promulgowania dekretu o heroiczności cnót s. Irene Stefani. Papież Benedykt XVI dnia 2 kwietnia 2011 r. upoważnił

53 Parte prima. Causa di canonizzazione di suor Irene Stefani - prove, w: Positio super vita..., s. 33-52.

54 Parte seconda. Profilo biografico..., s. 215.

55 Zob. szerzej: tamże, s. 216 i zamieszczone w przypisach 100 i 101 źródła.

56 Parte seconda. Profilo biografico..., s. 213.

57 Parte prima. Causa di canonizzazione..., s. 33-77.

58 Kan. 1418 KPK 1983.

59 Nyerien. seu Taurinen., Beatificationis et canonizationis Servae Dei Irenae Stefani, Sororis professae ex Instituto Sororum Missionariarum a Consolatione, Decretum super validate Processuum (29.01.1993), w: Positio super vita, virtutibus et fama sanctitatis..., s. 359. 
Kongregację do ogłoszenia dekretu super virtutibus ${ }^{60}$. W dekrecie odnotowano, że s. Irene w strasznych i beznadziejnych okolicznościach z nadzwyczajną słodyczą okazywała ofiarom wojny miłość i poświęcenie. Troszczyła się o ich zdrowie fizyczne i pożywienie (również duchowe). $\mathrm{Z}$ matczynym oddaniem nauczała, katechizowała, towarzyszyła dniem i nocą chorym oraz umierającym. Nazywano ją: "Matką czyniącą tylko miłosierdzie, samym miłosierdziem, łagodną matką, która wszystkich kocha najbardziej, ucieczką ubogich i aniołem miłosierdzia"61. Kiruku mówili na nią Mware mwendi ando - siostra, która czyni dobrze wszystkim, "Nyaatha" - „mamma tutta misericordia"62.

List apostolski wydany na beatyfikację papież Franciszek rozpoczął od słów z Ewangelii św. Mateusza:

Wtedy odezwie się Król do tych po prawej stronie: „Pójdźcie, błogosławieni Ojca mojego, weźcie w posiadanie królestwo, przygotowane wam od założenia świata! Bo byłem głodny, a daliście Mi jeść; byłem spragniony, a daliście Mi pić; byłem przybyszem, a przyjęliście Mnie; byłem nagi, a przyodzialiście Mnie; byłem chory, a odwiedziliście Mnie; byłem w więzieniu, a przyszliście do Mnie"63.

W homilii beatyfikacyjnej kard. John Njue podkreślił, że s. Irene Stefani dlatego jest przedstawiana jako wzór życia „młodym i starym”, ponieważ żyła zgodnie z Ewangelią. Jej życie było odzwierciedleniem Chrystusowych błogosławieństw ${ }^{64}$.

O beatyfikowanej 25 stycznia 2014 r. w Neapolu Marii Krystynie Sabaudzkiej (1812-1836), królowej Obojga Sycylii papież Franciszek powiedział, że była kobietą „o głębokiej duchowości i wielkiej pokorze”. Jej

${ }^{60}$ CCS, Nyeriensis seu Taurinensis. Beatificationis et canonizationis Servae Dei Irenae Stefani (in saec.: Aureliae Iacobae Mariae a Mercede), Sororis Professae Instituti Sororum Missionariarum a Consolata (1891-1930), Decretum super virtutibus (2.04.2011), AAS 104(2012), s. 645-648.

61 CCS, Nyeriensis seu Taurinensis. Decretum super virtutibus (2.04.2011), AAS 104(2012), s. 646.

62 A. Montonati, Il Vangelo del sorriso. Suor Irene Stefani missionaria della Consolata, Milano 2003, s. 79.

63 Franciscus, Litterae apostolicae Venerabili Servae Dei Irenae Stefani Beatorum honores decernuntur (23.05.2015), AAS 108(2016), s. 1195.

64 Omelia di sua Eminenza... 
przykład przedstawił zebranym na Placu św. Piotra w Światowy Dzień Chorych na Trąd. Podkreślił, że potrafiła

obarczyć się cierpieniem swojego ludu, stając się prawdziwą matką ubogich. Jej nadzwyczajny przykład miłosierdzia świadczy o tym, że dobre życie Ewangelią jest możliwe w każdym środowisku i w każdych warunkach społecznych ${ }^{65}$.

Ważnym odniesieniem dla współczesnych kobiet w każdym wieku i ze wszystkich środowisk jest świadectwo świeckiej mistyczki Edvige Carboni (1880-1952) z Sycylii. Mimo wielości charyzmatów (m.in. doświadczała bilokacji, ekstaz, lewitacji, dręczeń szatana, miała dar stygmatów, osmogenezy, widziała świętych) zawsze pozostawała skromna ${ }^{66}$. Cechowało ją „nieograniczone miłosierdzie, wielka pokora oraz nieustanna modlitwa”. Nie mówiła zbyt wiele, ale wiele czyniła, podążając za wolą Bożą, a nie swoimi pragnieniami. Jej przykład - jak wyjaśniał w wywiadzie dla Radia Watykańskiego kard. A. Becciu - uczy, że „prawdziwą świętość można wykuć w codziennym, nawet bardzo skromnym życiu" ${ }^{67}$.

\section{Zakończenie}

Papież Franciszek bardzo mocno akcentuje powszechność i „ogólnodostępność" powołania do świętości. Refleksję teologiczną Soboru Watykańskiego II wyłożoną w konstytucji dogmatycznej Lumen gentium przekłada na język przykładu. Czyni to przede wszystkim przez beatyfikacje i kanonizacje, w których zachęca do czerpania wzorów z życia nowych błogosławionych i świętych. Zastrzega jednak, że należy ich naśladować, a nie kopiować. Swoją uwagę kieruje w stronę kobiet. Pisząc w adhortacji apostolskiej Gaudete et exsultate o ich "geniuszu”, chociaż nie wprost, przywołuje list apostolski Jana Pawła II Mulieris dignitatem oraz

65 Franciszek, 26 stycznia [2014 r.], We wspótczesnej «Galilei pogan», [Modlitwa maryjna z Papieżem], OR 35(2014), nr 2(360), s. 55.

${ }^{66}$ Nuova beata. Edvige Carboni, la mistica che lottava per le anime del Purgatorio, https:/ / www.avvenire.it/chiesa/pagine/la-beatificazione-di-edvige-carboni-la-mistica-sarda [dostęp: 3.01.2020 r.].

67 Kard. Becciu: nowa błogostawiona wskazuje na niebo, https://www.vaticannews.va/ pl/watykan/news/2019-06/beatyfikacja-edwige-carboni.html [dostęp: 5.05.2020 r.]. 
przykłady kobiet wyniesionych na ołtarze przez papieża Wojtyłę i Benedykta XVI. Przywołane w niniejszym artykule sylwetki kobiet uświadamiają, że świętość jest powołaniem normalnym, osiągalnym w każdym wieku, stanie i zawodzie.

\section{Bibliografia}

\section{Literatura}

Borghesi M., Jorge Mario Bergoglio: biografia intelektualna: dialektyka i mistyka, Kraków 2018.

Fiejdasz-Buczek L., Sprawy kanonizacyjne za pontyfikatu papieża Benedykta XVI. Studium prawno-kanoniczne, Lublin 2019.

Franciszek - imię, które jest programem pontyfikatu, Niedziela 2013, nr 26.

Gli esordi di una missione straordinaria, Andare alle Genti: la rivista delle Missionarie della Consolata di informazione missionaria 69(2015), nr 9-10.

Herb i motto Papieża Franciszka, OR 34(2013), nr 5(352).

Inglot M., Ofiarowanie życia jako droga do świętości kanonizowanej według motu proprio papieża Franciszka Maiorem hac dilectionem z 11 lipca 2017 r., w: Prawo i praktyka kanonizacyjna za pontyfikatu papieża Franciszka, red. L. Fiejdasz-Buczek, Lublin 2019.

Ivereigh A., Tempo di misericordia: vita di Jorge Mario Bergoglio, Milano 2014.

Mariani A., Papa Francesco: misericordia, povertà e servizio: per una vita buona in compagnia di Maria, presentazione di Egidio Chiarella, Roma 2014.

Jorge Mario Bergoglio, OR 34(2013), nr 5(352).

Montonati A., Il Vangelo del sorriso. Suor Irene Stefani missionaria della Consolata, Milano 2003.

Papież, który przyjąt imię Franciszek, OR 34(2013), nr 5(352).

Valente G., Francesco, un papa dalla fine del mond: la persona, le idee, lo stile, Bologna 2013.

Vi chiedo di pregare per me: inizio del ministero petrino di papa Francesco, Città del Vaticano 2013.

\section{Materiały źródłowe ze stron internetowych}

Bilbao, 29 października 1945 roku, w: M. Del Rincón, M.T. Escobar, Listy do Śzwiętego, za: https://opusdei.org/pl-pl/document/listy-do-swietego/ [dostęp:1.05.2020r.].

Del Rincón M., Escobar M.T., Listy do Świętego, https://opusdei.org/pl-pl/document/listy-do-swietego/ [dostęp: 1.05.2020 r.]. 
Kard. Becciu: nowa btogostawiona wskazuje na niebo, https:/ /www.vaticannews.va/pl/ watykan/news/2019-06/ beatyfikacja-edwige-carboni.html [dostęp: 5.05.2020 r.]. List Papieża Franciszka z okazji beatyfikacji Guadalupe, Watykan, 12 kwietnia 2019 r., https:/ / opusdei.org/pl-pl/article/list-papieza-franciszka-z-okazji-beatyfikacji-guadalupe/ [dostęp: 1.04.2020 r].

Nuova beata. Edvige Carboni, la mistica che lottava per le anime del Purgatorio, https:// www.avvenire.it/chiesa/pagine/la-beatificazione-di-edvige-carboni-la-mistica-sarda [dostęp: 3.01.2020 r.].

Wszystko z miłości do Pana Boga. Biografia, za: https://opusdei.org/pl-pl/article/ wszystko-z-milosci-do-pana-boga/ [dostęp: 1.05.2020 r.].

\section{Streszczenie}

Papież Franciszek w swoim nauczaniu podkreśla, że powołanie do świętości jest powołaniem normalnym. Bardzo mocno akcentuje uświęcanie się w zwyczajnych okolicznościach codziennego życia, co wyraził w adhortacji apostolskiej Gaudete et exsultate o powszechnym powołaniu do świętości w świecie wspólczesnym. Franciszek pisze w niej o "świętych z sąsiedztwa”, czyli ludziach żyjących wokół nas, którzy z wielką miłością realizują swoje obowiązki. Zachęca, by czerpać wzory do naśladowania ze świętych i błogosławionych. Wśród nich zwraca szczególną uwagę na „"geniusz kobiecy» przejawiający się w kobiecych stylach świętości, niezbędnych do odzwierciedlenia świętości Boga na tym świecie". Dopełnieniem artykułu jest charakterystyka wybranych portretów niewiast beatyfikowanych z mandatu papieża Franciszka.

Słowa kluczowe: „,́więci z sąsiedztwa”, papież Franciszek, beatyfikacja, „geniusz kobiety", walor eklezjalny sprawy

\section{WOMEN BEATIFIED UNDER THE PONTIFICATE OF POPE FRANCIS - A SELECTION}

\section{Sum mary}

In his teaching Pope Francis stresses the fact that the call to holiness is universal. As emphasized in his apostolic exhortation Gaudete et exsultate on the call to holiness in today's world, sanctification can be gained through performing the ordinary daily duties of life. The pope refers to the saints "next-door," that is people who live among us and fulfil their duties with great love. He encourages us to follow the example of saints and the blessed and points to the "genius of woman" 
observable in "feminine styles of holiness, which constitute essential means of reflecting God's holiness in this world." The article is complemented by a characteristics of selected lay women who were beatified by the mandate of Pope Francis.

Key words: the saints "next-door," Pope Francis, beatification, "Genius Of Woman", ecclesiastical value of a case

\section{ИЗБРАННЫЕ ПОРТРЕТЫ ЖЕНЩИН, БЕАТИФИЦИРОВАННЫХ ВО ВРЕМЯ ПОНТИФИКАТА ПАПЫ ФРАНЦИСКА \\ Резюме}

В своем учении Папа Франциск подчеркивает, что призыв к святости - это естественное призвание. Особо подчеркивает достижение святости в обычных обстоятельствах повседневной жизни, что он выразил в Апостольском увещевании Gaudete et exsultate о всеобеем призвании к святости в современном мире. Франциск пишет в ней о «святых по соседству», то есть о людях вокруг нас, которые с большой любовью исполняют свои обязанности. Папа побуждает следовать примеру святых и блаженных. Среди них особое внимание обращает на “"гений женщины", который также проявляется в женских формах святости, необходимых для отражения Божьей святости в этом мире». Статья дополнена характеристиками избранных портретов женщин, беатифицированных Папой Франциском.

Ключевые слова: «святые по соседству», Папа Франциск, беатификация, «гений женщины», церковное значение вопроса 
